\title{
GMR
}

\section{Detection of damage on single- or double- stranded DNA in a population exposed to arsenic in drinking water}

\author{
J. Jiménez-Villarreal ${ }^{1,3}$, D.I. Rivas-Armendariz ${ }^{1}$, C.P. Pineda-Belmontes ${ }^{1}$, \\ N.D. Betancourt-Martínez ${ }^{1}$, M.A. Macías-Corral ${ }^{2}$, A.J. Guerra-Alanis ${ }^{1}$, \\ M.S Niño-Castañeda ${ }^{1}$ and J. Morán-Martínez ${ }^{1}$ \\ ${ }^{1}$ Departamento de Biología Celular y Ultraestructura, \\ Centro de Investigación Biomédica, Facultad de Medicina, \\ Universidad Autónoma de Coahuila, Torreón, Coahuila, México \\ ${ }^{2}$ CONACYT-CIMAV Unidad Durango, Durango, México \\ ${ }^{3}$ Departamento de Investigación, Escuela de Medicina, Unidad Norte, \\ Universidad Autónoma de Coahuila, Piedras Negras, Coahuila, México \\ Corresponding author: J. Morán-Martínez \\ E-mail.javmoran@yahoo.com \\ Genet. Mol. Res. 16 (2): gmr16029241 \\ Received September 12, 2016 \\ Accepted April 10, 2017 \\ Published May 18, 2017 \\ DOI http://dx.doi.org/10.4238/gmr16029241
}

Copyright (C) 2017 The Authors. This is an open-access article distributed under the terms of the Creative Commons Attribution ShareAlike (CC BY-SA) 4.0 License.

\begin{abstract}
Different studies have suggested an association between arsenic (As) exposure and damage to single-stranded DNA by reactive oxygen species derived from the biotransformation of arsenic. The single strand damages are converted to double strand damage upon interaction with ultraviolet radiation. Analysis of genomic integrity is important for assessing the genotoxicity caused by environmental pollutants. In this study, we compared the concentration of As in drinking water, nutritional status, lifestyle variables, and the level of genotoxicity in an exposed population and a control group. Arsenic content of water was determined using a portable Arsenator ${ }^{\circledR}$ kit. DNA fragmentation was determined using the two-tailed comet assay. Our results show that
\end{abstract}

Genetics and Molecular Research 16 (2): gmr16029241 
the exposed population had low nutritional consumption compared to the control group $(\mathrm{P}<0.05)$. Furthermore, the water consumed by the exposed group had As concentration of $14.3 \pm 8.4 \mathrm{mg} / \mathrm{L}$, whereas the As level in the water consumed by the control group was $7.7 \pm 3.5$ $\mathrm{mg} / \mathrm{L}$. Analysis shows that the frequency of double strand break (DSB) fragmentation was higher in the population exposed to higher levels of As compared to that of the control group. These results suggest a possible association between the concentration of As in drinking water and lifestyle variables, with increasing fragmentation of DSBs in the exposed population.

Key words: Arsenic; Two-tailed comet assay; Single-stranded DNA breaks; Double-stranded DNA breaks

\section{INTRODUCTION}

Arsenic (As) is a toxic metalloid that generates reactive oxygen species (ROS) and oxidative stress (OS) (Nava and Méndez, 2011). OS, generated mainly by the biotransformation of As, induces DNA damage. The increase in ROS levels and decrease in levels of enzymes involved in anti-oxidative processes generate alterations in signaling pathways, activate caspases, and induce apoptosis (Abernathy et al., 2003). In addition, ROS alters DNA repair processes, methylation patterns, and gene expression (Dong, 2002; Hartwig et al., 2003). The International Agency for Research on Cancer (IARC) has classified As in water as a cause of human cancer (IARC, 2002; Dauphiné et al., 2013). The types of cancer associated with exposure to As via water are liver, kidney, skin, lung, and colon cancers (Xia et al., 2009; Dauphiné et al., 2013; Mostafa and Cherry, 2015). Bangladesh, India, Taiwan, Argentina, Chile, China, Hungary, Japan, Mongolia, Poland, the United States, Canada, Nepal, Vietnam, Italy, Finland, Spain, New Zealand, and Mexico are the countries that have reported As contamination in water (Islam et al., 2004; Hoque and Butler, 2015). The World Health Organization (WHO), the United States, and the European Union have established the permissible exposure limit of As in water as $10 \mu \mathrm{g} / \mathrm{L}$. Mexico have established $25 \mu \mathrm{g} / \mathrm{L}$, and Bangladesh $5 \mu \mathrm{g} / \mathrm{L}$ (Chowdhury et al., 2000; NOM-127-SSA1-1994; Khalequzzaman et al., 2005). Cancers connected with As in water have been associated with cellular, molecular, and genetic modifications such as repression of DNA repair genes, alteration in gene expression and methylation, micronucleus formation, chromosomal aberrations, polymorphisms, genotoxicity, cytotoxicity, telomere shortening, decreased DNA damage response (DDR), and DNA damage (Murray and Sharmin, 2015; Shibata et al., 2016; Akter et al., 2016). The principal factors regulating DNA damage are diet, alcohol consumption, age, smoking, exercise, and exposure to environmental toxins such as asbestos, heavy metals, radiation (ultraviolet (UV) light, gamma rays), and stress (Gidron et al., 2006). Arsenic directly induces single strand breaks (SSB) via formation of ROS, and it can also induce double strand breaks (DSB) upon interaction with UV as a co-carcinogen (Aitken and Krausz, 2001; Faita et al., 2013). DNA integrity is preserved by the DNA damage response (DDR) pathways, which halt the cell cycle for repair events in the presence of damage. The DDR is orchestrated by a complex of proteins that perform genome repair (Rossiello et al., 2014). DSB is the most deleterious damage because it causes apoptosis, genomic instability, and cancer, and is difficult to repair (Jackson and Bartek, 2009).

Genetics and Molecular Research 16 (2): gmr16029241 
The evaluation of environmental exposure to As via water is important due to its impact on human health. Biomonitoring can quantify the extent of exposure and the response of the human body to environmental As exposure (Chanpiwat et al., 2015). DNA fragmentation is an important parameter in determining the genotoxicity of environmental contaminants. The comet assay is used to evaluate DNA fragmentation; two types of comets, alkaline and neutral, were developed, respectively, by Singh et al. (1988) and Olive et al. (1991). However, these methods are unable to differentiate between SSB and DSB in the same cell. The presence of DSB and SSB fragmentation in the same cell may have important clinical implications, and thus, the identification and evaluation of these two types of damages is important at the cellular level. The two-tailed comet assay (TTC) is a new standardized technique capable of evaluating DSBs and SSBs in the same cell. TTC is a rapid, sensitive, and reliable method for the characterization of DNA damage in genotoxic assessment (Enciso et al., 2009). The relationship between exposure to As and extent of DNA damage is another important issue that requires investigation. Therefore, the objective of this study is to determine the relationship between the concentration of As in drinking water of an exposed population and the extent of SSB and DSB, and compare it with the results of a control group.

\section{MATERIAL AND METHODS}

\section{Study area}

The study was conducted in the community of Ejido El Lequeitio, located in the

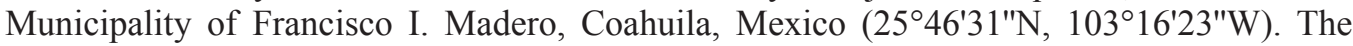
study area was categorized as contaminated by arsenic, the levels of which were higher than the permissible exposure limits. Based on studies of genotoxicity of exposure (Tian et al, 2001; Bartolotta et al, 2011), the experimental design included exposed and control subjects in 188 participants.

\section{Data collection}

All participants signed a letter of informed consent. The research was approved with the reference number AUT 02-05/14 by the Honorable Bioethics Committee of the School of Medicine of the Autonomous University of Coahuila (Torreon, Coahuila, Mexico) and the Ministry of Health and the National Bioethics Commission in Mexico (Reference No. CONBIOETICA07CEI00320131015). Patient selection was random, with confidence intervals (CI) 95\% statistical power to the study. All subjects completed a questionnaire that included the following information: personal data, lifestyle, history of drug and water consumption, reproductive history, work environment, and nutritional status (based on Mexican Official Standard NOM-043-SSA2 -2012). Nutritional status and body mass index (BMI) were interpreted according to federal standards NOM-008-SSA3-2010. The inclusion criteria for the exposed group were as follows: two or more years of residence in the study area, similar socioeconomic status, level of arsenic in water $>10 \mu \mathrm{g} / \mathrm{L}$. The exclusion criteria were exposure to pesticides, solvents, and gasoline, presence of cancer and/or administration of chemotherapy. The inclusion criteria for the control group were: more than two years of residence in the study area, similar socioeconomic status, level of arsenic in water $\leq 10 \mu \mathrm{g} / \mathrm{L}$. The exclusion criteria were exposure to pesticides, solvents, and gasoline, presence of cancer, and/or administration of chemotherapy.

Genetics and Molecular Research 16 (2): gmr16029241 


\section{Assessment of arsenic exposure}

The exposure assessment in the study area was conducted by collecting household water samples. Arsenic concentration was determined according to the instructions of the Wag-WE10500 Wagtech Digital technique Arsenator ${ }^{\circledR}$ (Erlanger, KY, USA) commercial portable kit, which has been validated by other studies (Kinniburgh and Kosmus, 2002; Safarzadeh-Amiri et al., 2011). The Arsenator ${ }^{\mathbb{B}}$ was calibrated in triplicate before use with standard solutions containing $0,10,25,50$, and $75 \mu \mathrm{g} / \mathrm{L}$ As.

\section{Genotoxicity assessment}

The genotoxic evaluation study was performed on peripheral blood leukocytes of subjects exposed to arsenic and residing for more than 2 years in the study area; extraction was by venipuncture into a BD $4 \mathrm{~mL}$ Vacutainer $^{\mathbb{B}}\left(7.2 \mathrm{mg}\right.$ of $\mathrm{k}_{2} \mathrm{E} / \mathrm{k}_{2}$ EDTA). The leukocyte samples were processed according to the TTC technique developed by Enciso et al. (2009) with some modifications in the incubation time of the samples and electrophoresis conditions, especially, in the volume and concentration of the solutions. DNA was stained with GelGreen ${ }^{\mathrm{TM}}$ (Nucleic Acid Gel Stains, Biotium ${ }^{\circledR}$, Fremont, CA USA) in phosphate buffered saline (PBS). Comets were visually analyzed and the images were processed as explained below; The DNA fragmentation index (DFI) was obtained by counting 500 comets per slide and cells were classified as without damage (no DNA migration) or damaged (DNA migration). The tails of comets oriented in the X-axis represent double strand breaks (DSBs) and tails of comets oriented in the Y-axis represent single strand breaks (SSBs). Comets were classified into seven types according to the length of the tail (fragmented DNA): 1, without damage; 2, low level of SSB damage; 3, high level of SSB damage; 4, low level of DSB damage; 5, high level of DSB damage; 6, low level SSB and low level DSB; 7, high level of SSB and high level DSB. The TTCs were observed with a fluorescence microscope (LX 400, LABOMED, Germany) and images were captured with fluorescent high resolution camera (IVU 7000, Jenopik, Germany). The ImageJ V.1.8.0 software (Collins, 2007) was used for the visual classification of TTC.

\section{Statistical analysis}

Results are reported as means \pm standard deviation, and categorical variables are expressed in percentage and were analyzed by the chi square test. For the $t$-test, two independent samples were used to observe the differences between groups, and the Mann Whitney U-test was used for differences between groups of categorical variables with nonnormal distribution. The Pearson correlation analysis was used for the association of variables, bivariate analysis for the association of variables with genotoxic effect, and multivariate analysis for the modifying effect variables associated with genotoxic damage. $\mathrm{P}<0.05$ was considered to be statistically significant for the analyses.

\section{RESULTS}

\section{Analysis of arsenic exposure}

Results showed that the concentration of As in the drinking water consumed by the

Genetics and Molecular Research 16 (2): gmr16029241 
test subjects was above the current permissible limit (WHO, 2004). The exposed group was statistically different from the control group $(\mathrm{P}<0.05)$. The exposure range of arsenic in water was 11.2-17.4 $\mu \mathrm{g} / \mathrm{L}$ for the exposed group, whereas it was $6.4-9.1 \mu \mathrm{g} / \mathrm{L}$ for the control group. The average time for exposure was $4 \pm 0.11$ years for the test group, whereas it was $3 \pm 0.07$ years for the control group.

\section{Sociodemographic analyses}

Analysis of sociodemographic variables showed that the groups varied only in lifestyle factors and not in the occurrence of chronic diseases. There was no statistical difference between the groups in terms of presence of diabetes, hypertension, and anemia, which might affect the health of participants. The sociodemographic and lifestyle characteristics of the participant population are shown in Table 1. The main lifestyle variables were associated with the development of chronic diseases and other conditions. Evaluation of the nutritional intake (grams) of protein, lipids, and carbohydrates $(\mathrm{CH})$ between the evaluated groups showed that nutritional status was significantly different between the exposed group and the control group (Figure 1). The differences in the nutritional intake of protein, lipids, and $\mathrm{CH}$ between the groups may be due to socioeconomic differences as the studied area is classified as a rural area.

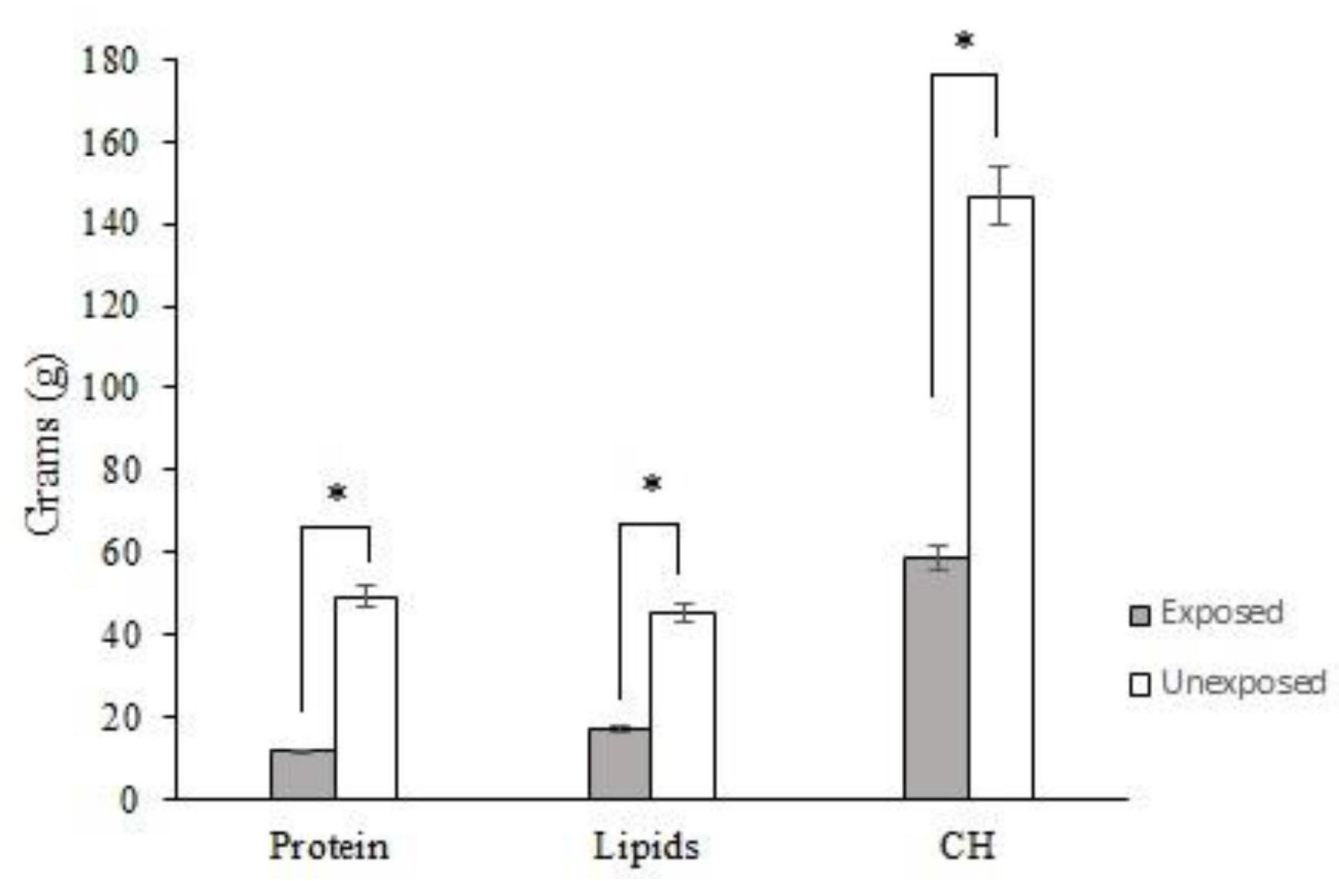

Figure 1. Nutritional analysis by group. Differences in consumption in grams per input/day of protein, lipids and carbohydrates $(\mathrm{CH}) .{ }^{*} \mathrm{P}<0.05, t$-test for 2 independent samples.

Genetics and Molecular Research 16 (2): gmr16029241 
Table 1. Group-wise sociodemographic characteristics of the study population.

\begin{tabular}{l|c|c}
\hline \multirow{2}{*}{ Variable } & \multicolumn{2}{|c}{ Group } \\
\cline { 2 - 3 } & Exposed (Means \pm SD) & $32 \pm 9.9$ \\
\hline $\mathrm{N}$ & 76 & $27.28 \pm 4.8$ \\
\hline Age & $27.4 \pm 5.3$ & $66.9^{* *}$ \\
\hline BMI & $29.20 \pm 3.9$ & $33.0^{* *}$ \\
\hline Not & & $50^{* *}$ \\
\hline Yes & 34.2 & $50^{* *}$ \\
\hline Alcohol consumption (\%) & 65.7 & $68.7^{* *}$ \\
\hline Not & & $31.2^{* *}$ \\
\hline Yes & 21.0 & 94.6 \\
\hline Exposure to heat $\geq 39^{\circ} \mathrm{C}(\%)$ & 78.9 & 5.3 \\
\hline Not & & \\
\hline Yes & 51.3 & 93.7 \\
\hline Diabetes & 48.6 & 6.2 \\
\hline Not & & \\
\hline Yes & 93.4 & 97.3 \\
\hline Hypertension & 6.5 & 2.6 \\
\hline Not & & \\
\hline Yes & 98.6 & \\
\hline Anemia & 1.3 & \\
\hline Not $(\%)$ & & \\
\hline Yes $(\%)$ & 100 & \\
\hline
\end{tabular}

**Statistically significant $\mathrm{P}<0.05$, Chi square - no data.

\section{Genotoxicity analysis}

We analyzed the leukocytes of subjects exposed to 11.2-17.4 $\mu \mathrm{g} / \mathrm{L}$ As in drinking water (exposed group) or 6.4-9.1 $\mu \mathrm{g} / \mathrm{L}$ of As (control group) using the two-tailed comet assay. Fluorescence microscopic assessment of DNA fragmentation showed different types of damage. The observed comets were classified as mentioned in Materials and Methods. As shown in Figure 2, comets were stained with GelGreen ${ }^{\mathrm{TM}}$ (left-hand side images) and were contrasted with an electronic filter (Find EDGES) for assessing fragmentation (righthand side images). Cells without DNA damage (Figure 2a), with high DSB (Figure 2b), high SSB (Figure 2c), and DSB and SSB damage in the same cell (Figure 2d) were observed. The result of the visual classification and enumeration of comets with DNA fragmentation is shown in Figure 3. In all categories, the fragmentation observed in the DNA of the exposed group was significantly and statistically different from that of the control group; however, comets registered a higher number of cells in the "high DSB" and "low SSB" categories in the exposed group compared to those in the control group $(\mathrm{P}<0.05)$. Furthermore, the results show nonparametric distribution in the frequency of DSB and SSB in both groups. Figure 3 shows the number of damaged cells in the exposed group.

The DNA fragmentation index (Table 2), shows difference in the percentage of DSB between the two groups; however, there was no difference in SSB-DFI between the two groups. This suggests that exposure to As through drinking water is associated with lifestyle variables that increase the possibilities of DSB.

Correlation of biologically relevant variables with DSB and SSB damage were considered at $\mathrm{P}$ value $<0.05$. Only the variable "exposure $\geq 39^{\circ} \mathrm{C}$ " was associated with SSB DNA fragmentation in the bivariate regression analysis (Table 3). The interactions of lifestyle variables with arsenic exposure were associated with increased DNA fragmentation, and all the variables analyzed were associated with DSB DNA fragmentation except for basal metabolic index (BMI).

Genetics and Molecular Research 16 (2): gmr16029241 
Without damage

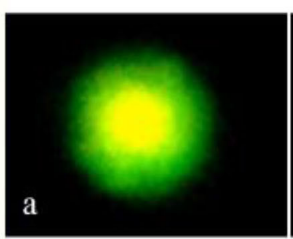

High SSBs
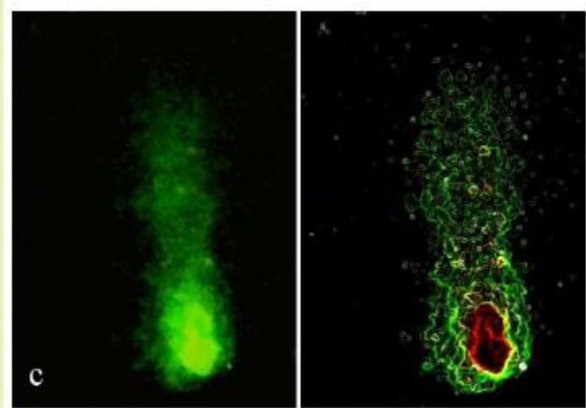

High DSBs

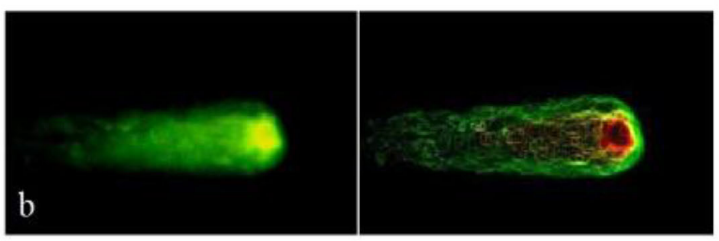

High SSBs and High DSBs

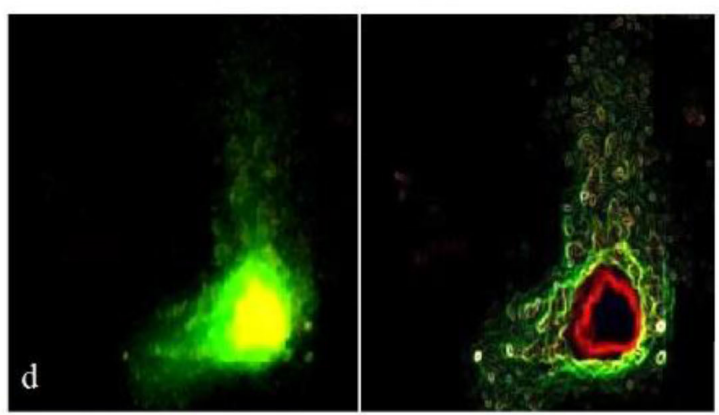

Figure 2. Representation of comets evaluated in different categories. a. Basal DNA structure in good condition; $\mathbf{b}$. migration of DNA-DSB; c. SSB damage; d. DNA fragmentation in DSB and SSB in the same cell. Cells stained With GelGreen $^{\mathrm{TM}}$ (right-side images) and with electronic filter (left-side images) at 100X magnification.

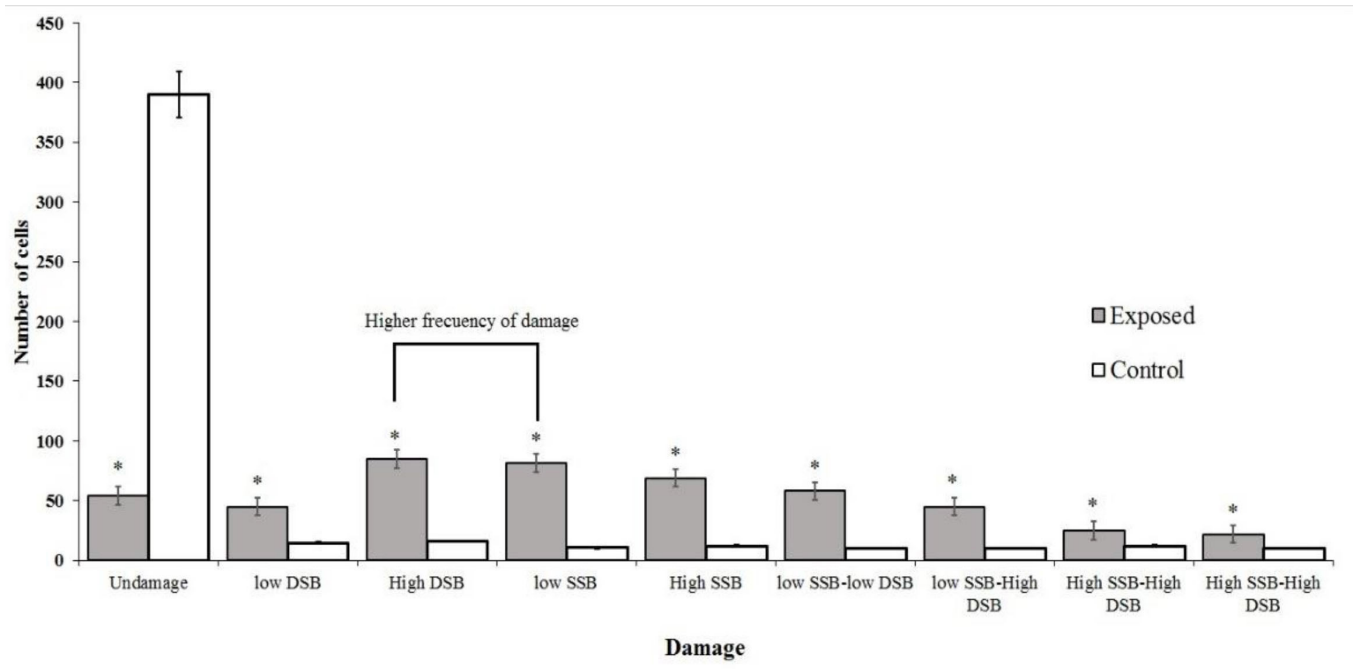

Figure 3. Absolute frequency of cells counted using the TTC assay. Number of cells with fragmented DNA (DSB and SSB) in leukocytes from both groups were plotted. The histogram shows the number of cells without damage, with DSB, and SSB in both groups. $* \mathrm{P}<0.05$, Mann-Whitney U-test compared to the control group.

Genetics and Molecular Research 16 (2): gmr16029241 
Table 2. Fragmentation index of SSB and DSB.

\begin{tabular}{l|c|c}
\hline DNA Damage (\%) & Exposed (Means \pm SD) & Control (Means \pm SD) \\
\hline DSB-DFI & $32.5 \pm 5.7$ & $19.7 \pm 4.7^{*}$ \\
\hline SSB-DFI & $30.3 \pm 6.1$ & $31.7 \pm 9.9$ \\
\hline
\end{tabular}

DSB-DFI = double strand breaks-DNA fragmentation index. SSB-DFI = single strand breaks-DNA fragmentation index. *Statistically significant $\mathrm{P}<0.05 ; t$-test, 2 independent samples.

Table 3. $\mathrm{r}^{2}$ values of correlation and bivariate regression analysis of variables associated with DNA damage in DSB and SSB.

\begin{tabular}{|c|c|c|c|c|c|c|c|c|c|c|}
\hline \multirow{3}{*}{ Variable } & \multicolumn{4}{|c|}{ Correlation analysis } & \multicolumn{6}{|c|}{ Bivariate regression analysis } \\
\hline & \multicolumn{2}{|c|}{ DSB } & \multicolumn{2}{|c|}{ SSB } & \multicolumn{3}{|c|}{ DSB } & \multicolumn{3}{|c|}{ SSB } \\
\hline & $\mathrm{r}^{2}$ & $\mathrm{P}$ & $\mathrm{r}^{2}$ & $\mathrm{P}$ & Coef.. & Std. Err. & $\mathrm{P}$ & Coef.. & Std. Err. & $P$ \\
\hline Exposed to As & 0.77 & $<0.001$ & -0.08 & $<0.27$ & 1.92 & 0.11 & $<0.001$ & -0.02 & 0.19 & $<0.27$ \\
\hline Age & -0.17 & $<0.01$ & 0.05 & $<0.04$ & -0.16 & 0.06 & $<0.001$ & 0.05 & 0.07 & $<0.46$ \\
\hline BMI & 0.08 & $<0.24$ & -0.01 & $<0.81$ & 0.14 & 0.12 & $<0.24$ & -0.03 & 0.13 & $<0.8$ \\
\hline Smoking & 0.02 & $<0.001$ & 0.01 & $<0.85$ & 3.97 & 1.16 & $<0.001$ & 0.23 & 1.26 & $<0.80$ \\
\hline Alcohol consumption & 0.32 & $<0.001$ & 0.005 & $<0.94$ & 5.47 & 1.15 & $<0.001$ & 0.09 & 1.3 & $<0.93$ \\
\hline Exposure to heat $\geq 39^{\circ} \mathrm{C}$ & 0.11 & $<0.01$ & 0.16 & $<0.01$ & 2.96 & 1.20 & $<0.015$ & 3.01 & 1.28 & $<0.02$ \\
\hline
\end{tabular}

The association coefficient of the variable "exposure to As" showed interaction with lifestyle variables $(\mathrm{P}<0.05)$ associated with the development of DSBs and SSBs. However, a positive association $(\mathrm{P}<0.05)$ was observed when the exposure to As was adjusted with lifestyle variables that showed associations with the development of DSB fragmentation but not with SSB (Table 4).

Table 4. Multivariate regression analysis and its relationship with increased DNA fragmentation in DSB and SSB.

\begin{tabular}{l|c|c|c|c|c|c}
\hline & \multicolumn{3}{|c|}{ DSB } & \multicolumn{3}{c}{ SSB } \\
\cline { 2 - 7 } & Coef. & Std. error & P & Coef. & Std. error & P \\
\hline As exposure (crude) & 1.92 & 0.11 & $<0.001$ & -0.021 & 0.19 & $<0.27$ \\
\hline As exposure $^{\mathrm{a}}$ (adjusted) & 1.87 & 0.13 & $<0.001$ & -0.33 & 0.21 & $<0.123$ \\
\hline
\end{tabular}

${ }^{a}$ Multivariate regression analysis adjusted for variables such as age, smoking, alcohol consumption, exposure to $\geq 39^{\circ} \mathrm{C}$. Coef., coefficient; Std. error, standard error.

\section{Limit of detection of the TTC assay}

DNA damage in the exposed group and control group indicated that the TTC test can detect DNA fragmentation in the aqueous arsenic range used in our study. The arsenic content in water consumed by both groups is above $1 \mu \mathrm{M}$, the arsenic concentration that has been reported to initiate DNA damage.

\section{DISCUSSION}

Arsenic produces reactive oxygen species (ROS), induces genotoxicity, and is associated with cancer. Arsenic toxicity inactivates approximately 200 enzymes, mostly involved in DNA damage repair, DNA replication, and cellular energy pathways (Ratnaike, 2003). Genotoxicity of arsenic does not directly affect DNA, but rather acts indirectly through ROS (Basu et al., 2005). One micromolar As is sufficient to interfere with the activity of

Genetics and Molecular Research 16 (2): gmr16029241 
adenosine diphosphate poly-ribose polymerase-1 (PARP-1), thereby increasing SSB and DSB fragmentation (Qin et al., 2008). Sampling of peripheral blood via venipuncture is the best way to evaluate the genotoxic effects of arsenic in exposed population in a minimally invasive way (Basu et al., 2005; Palus et al., 2005; Vuyyuri et al., 2006; Banerjee et al., 2008; Jasso-Pineda et al., 2012). The time of exposure to arsenic is an important parameter for determination of genotoxic damage. Certain studies have demonstrated an association of exposure time to arsenic with DNA damage by evaluation of peripheral blood. This time was estimated to be 5 years in Bengal, (Basu et al., 2005), 18 years in Poland (Palus et al., 2005), 3 years in the study by Vuyyuri et al. (2006), 10 years in the study of Banerjee et al. (2008), and San Luis Potosi, Mexico (Jasso-Pineda et al. 2012) evaluated 6 years of exposition of arsenic. Basu et al. (2005) reported 59.74\% \pm 10.54 DNA damage and Palus et al. (2005) showed tail moment of $13.2 \mathrm{x}$ $10^{-3}$ for DNA fragmentation. Vuyyuri et al. (2006) showed an increase of $14.95 \pm 0.21 \mu \mathrm{m}$ in the tail length of fragmented comets, whereas Banerjee et al. (2008) showed an Olive tail moment of $2.76 \pm 1.39$ of damaged DNA, and Jasso-Pineda et al. (2012) reported significant damage while evaluating tail moment of $5.2 \pm 0.6,3.5 \pm 0.4$, and $2.5 \pm 0.4$. Our results are similar to the published results regarding DNA fragmentation upon environmental exposure to arsenic. We observed $32.5 \pm 5.7 \%$ DSB-DFI and $30.3 \pm 6.1 \%$ SSB-DFI in our subjects.

The parameters used for evaluating DNA fragmentation vary among studies; however, the comet assay is commonly used for assessing DNA damage in populations that are environmentally exposed to arsenic. There are two types of comet assays: 1) the neutral comet assay (Olive et al., 1991), in which DNA migrates under neutral conditions, for identification of double-stranded DNA breaks (DSB), and 2) the alkaline comet assay, in which DNA is mobilized under alkaline conditions for DNA denaturation. The latter technique detects both SSB and DSB, without distinguishing between the two (Singh et al., 1988).

The main parameters used for evaluating arsenic-induced genotoxicity in the comet assay are comet tail length, tail moment, and percentage of tail DNA (Vuyyuri et al., 2006; Banerjee et al., 2008; Jasso-Pineda et al., 2012). The statistical analysis used in each study is different, which renders interpretation of fragmentation difficult. In addition, these studies used single parameter in their analysis and did not assess the occurrence of both types of fragmentation simultaneously in the same cell. Continuous sampling from the exposed population and the control group within this population would detect an increase or significant change in DNA damage, which would suggest changes in lifestyle for reduction of damage. We used the two-tailed comet assay developed by Enciso et al. (2009) with slight modification, which is being increasingly used for evaluating DNA fragmentation in several studies with clinical application (Enciso et al., 2009; Ribas-Maynou et al., 2012). This technique evaluates the occurrence of both SSB and DSB in a single cell. We evaluated DNA fragmentation in a population naturally exposed to arsenic and studied its interaction with other variables. Results show that exposure to arsenic increases DNA fragmentation significantly as reported in other studies (Vuyyuri et al., 2006; Banerjee et al., 2008; Jasso-Pineda et al., 2012). Therefore, we used TTC as a biomonitoring technique to show that exposure to arsenic increases DSB fragmentation in the exposed population. In addition, we demonstrated interaction of the extent of damage with lifestyles variables because these variables modify the effect of the damage caused by environmental exposure to arsenic. However, we suggest inclusion of additional information for distinguishing between the associations of SSB and DSB with the presence of several diseases including cancer in the population environmentally exposed to arsenic. Generally, DSBs are considered more interesting than SSBs due to the rapidity of their repair

Genetics and Molecular Research 16 (2): gmr16029241 
kinetics (Jackson and Bartek, 2009). Therefore, further research is required for determining the biological impact of SSBs and DSBs on the health of the exposed population. Here, we established TTC as a method for detecting DNA fragmentation upon exposure to arsenic in water in a concentration range of 6.4-9.1 $\mu \mathrm{g} / \mathrm{L}$.

In conclusion, a continuous analysis of the concentration of arsenic in water can reduce arsenic exposure, and TTC is a sensitive, reliable, and rapid methodology for determining the extent of genotoxic damage in exposed people. Frequent analysis of DNA fragmentation might promote lifestyle change and thereby alter the interaction of these variables with arsenic toxicity, which is associated with high levels of DSB. In summary, we showed that As is an environmental toxin associated with DNA damage in exposed people. We believe that our results would clarify the type of DNA fragmentation induced by As exposure through drinking water using the TTC technique. The limitations of this study are the inability to analyze the concentration of arsenic (or its metabolic by-products) in biological samples such as blood and urine for establishing a relationship between individual concentrations in the study subjects and their level of personal genotoxicity.

\section{Conflicts of interest}

The authors declare no conflict of interests.

\section{ACKNOWLEDGMENTS}

We thank Dr. G. Hankings of the West Virginia State University, for critical reading of the manuscript and CONACyT for grant \#378398.

\section{REFERENCES}

Abernathy CO, Thomas DJ and Calderon RL (2003). Health effects and risk assessment of arsenic. J. Nutr. 133 (Suppl 1): $1536 \mathrm{~S}-1538 \mathrm{~S}$.

Aitken RJ and Krausz C (2001). Oxidative stress, DNA damage and the Y chromosome. Reproduction 122: $497-506$. http://dx.doi.org/10.1530/rep.0.1220497

Akter T, Jhohura FT, Akter F, Chowdhury TR, et al. (2016). Water Quality Index for measuring drinking water quality in rural Bangladesh: a cross-sectional study. J. Health Popul. Nutr. 35: 4. http://dx.doi.org/10.1186/s41043-016-0041-5

Banerjee M, Sarma N, Biswas R, Roy J, et al. (2008). DNA repair deficiency leads to susceptibility to develop arsenicinduced premalignant skin lesions. Int. J. Cancer 123: 283-287. http://dx.doi.org/10.1002/ijc.23478

Bartolotta SA, Pacskowski MG, Hick A and Carballo MA (2011). Micronuclei assay in exfoliated buccal cells from individuals exposed to arsenic in Argentina. Arch. Environ. Contam. Toxicol. 61: 337-343. http://dx.doi.org/10.1007/ $\underline{\mathrm{s} 00244-010-9607-1}$

Basu A, Som A, Ghoshal S, Mondal L, et al. (2005). Assessment of DNA damage in peripheral blood lymphocytes of individuals susceptible to arsenic induced toxicity in West Bengal, India. Toxicol. Lett. 159: 100-112. http://dx.doi. org/10.1016/j.toxlet.2005.05.001

Chanpiwat P, Himeno S and Sthiannopkao S (2015). Arsenic and other metals' presence in biomarkers of Cambodians in arsenic contaminated areas. Int. J. Environ. Res. Public Health 12: 14285-14300. http://dx.doi.org/10.3390/ ijerph121114285

Chowdhury UK, Biswas BK, Chowdhury TR, Samanta G, et al. (2000). Groundwater arsenic contamination in Bangladesh and West Bengal, India. Environ. Health Perspect. 108: 393-397. http://dx.doi.org/10.1289/ehp.00108393

Collins TJ (2007). ImageJ for microscopy. Biotechniques 43 (Suppl): 25-30. http://dx.doi.org/10.2144/000112517

Dauphiné DC, Smith AH, Yuan Y, Balmes JR, et al. (2013). Case-control study of arsenic in drinking water and lung cancer in California and Nevada. Int. J. Environ. Res. Public Health 10: 3310-3324. http://dx.doi.org/10.3390/ ijerph10083310

Genetics and Molecular Research 16 (2): gmr16029241 
Dong Z (2002). The molecular mechanisms of arsenic-induced cell transformation and apoptosis. Environ. Health Perspect. 110 (Suppl 5): 757-759. http://dx.doi.org/10.1289/ehp.02110s5757

Enciso M, Sarasa J, Agarwal A, Fernández JL, et al. (2009). A two-tailed Comet assay for assessing DNA damage in spermatozoa. Reprod. Biomed. Online 18: 609-616. http://dx.doi.org/10.1016/S1472-6483(10)60003-X

Faita F, Cori L, Bianchi F and Andreassi MG (2013). Arsenic-induced genotoxicity and genetic susceptibility to arsenicrelated pathologies. Int. J. Environ. Res. Public Health 10: 1527-1546. http://dx.doi.org/10.3390/ijerph10041527

Gidron Y, Russ K, Tissarchondou H and Warner J (2006). The relation between psychological factors and DNA-damage: a critical review. Biol. Psychol. 72: 291-304. http://dx.doi.org/10.1016/j.biopsycho.2005.11.011

Hartwig A, Pelzer A, Asmuss M and Bürkle A (2003). Very low concentrations of arsenite suppress poly(ADP-ribosyl) ation in mammalian cells. Int. J. Cancer 104: 1-6. http://dx.doi.org/10.1002/ijc.10911

Hoque MA and Butler AP (2015). Medical hydrogeology of Asian deltas: status of groundwater toxicants and nutrients, and implications for human health. Int. J. Environ. Res. Public Health 13: 81. http://dx.doi.org/10.3390/ijerph13010081

IARC - International Agency for Research on Cancer (2002). Some drinking-water disinfectants and contaminants, including arsenic. In Monographs on the Evaluation of Carcinogenic Risks to Humans; Lyon, France, Vol. 84.

Islam LN, Nabi AH, Rahman MM, Khan MA, et al. (2004). Association of clinical complications with nutritional status and the prevalence of leukopenia among arsenic patients in Bangladesh. Int. J. Environ. Res. Public Health 1: 74-82. http://dx.doi.org/10.3390/ijerph2004020074

Jackson SP and Bartek J (2009). The DNA-damage response in human biology and disease. Nature 461: 1071-1078. http:// dx.doi.org/10.1038/nature 08467

Jasso-Pineda Y, Díaz-Barriga F, Calderón J, Yáñez L, et al. (2012). DNA damage and decreased DNA repair in peripheral blood mononuclear cells in individuals exposed to arsenic and lead in a mining site. Biol. Trace Elem. Res. 146: 141149. http://dx.doi.org/10.1007/s12011-011-9237-0

Khalequzzaman M, Faruque FS and Mitra AK (2005). Assessment of arsenic contamination of groundwater and health problems in Bangladesh. Int. J. Environ. Res. Public Health 2: 204-213. http://dx.doi.org/10.3390/ijerph2005020002

Kinniburgh DG and Kosmus W (2002). Arsenic contamination in groundwater: some analytical considerations. Talanta 58: 165-180. http://dx.doi.org/10.1016/S0039-9140(02)00265-5

Mostafa MG and Cherry N (2015). Arsenic in drinking water, transition cell cancer and chronic cystitis in rural Bangladesh. Int. J. Environ. Res. Public Health 12: 13739-13749. http://dx.doi.org/10.3390/ijerph121113739

Murray MP and Sharmin R (2015). Groundwater arsenic and education attainment in Bangladesh. J. Health Popul. Nutr. 33: 20. http://dx.doi.org/10.1186/s41043-015-0029-6

Nava RC and Méndez AM (2011). Efectos neurotóxicos de metales pesados (cadmio, plomo, arsénico y talio). Arch. Neurocien. (Mex) 16: 140-147.

Norma Oficial Mexicana NOM-008-SSA3-2010 Para el tratamiento integral del sobrepeso y la obesidade, 1-8.

Norma Oficial Mexicana NOM-043-SSA2-2012 Servicios básicos de salud. Promoción y educación para la salud en materia alimentaria, 1-79.

Norma Oficial Mexicana NOM-127-SSA1-1994 Salud ambiental, agua para uso y consumo humano-límites permisibles de calidad y tratamientos a que debe someterse el agua para su potabilización, 1-8.

Olive PL, Wlodek D and Banáth JP (1991). DNA double-strand breaks measured in individual cells subjected to gel electrophoresis. Cancer Res. 51: 4671-4676.

Palus J, Lewinska D, Dziubaltowska E, Stepnik M, et al. (2005). DNA damage in leukocytes of workers occupationally exposed to arsenic in copper smelters. Environ. Mol. Mutagen. 46: 81-87. http://dx.doi.org/10.1002/em.20132

Qin XJ, Hudson LG, Liu W, Timmins GS, et al. (2008). Low concentration of arsenite exacerbates UVR-induced DNA strand breaks by inhibiting PARP-1 activity. Toxicol. Appl. Pharmacol. 232: 41-50. http://dx.doi.org/10.1016/j. taap.2008.05.019

Ratnaike RN (2003). Acute and chronic arsenic toxicity. Postgrad. Med. J. 79: 391-396. http://dx.doi.org/10.1136/ pmj.79.933.391

Ribas-Maynou J, García-Peiró A, Abad C, Amengual MJ, et al. (2012). Alkaline and neutral Comet assay profiles of sperm DNA damage in clinical groups. Hum. Reprod. 27: 652-658. http://dx.doi.org/10.1093/humrep/der461

Rossiello F, Herbig U, Longhese MP, Fumagalli M, et al. (2014). Irreparable telomeric DNA damage and persistent DDR signalling as a shared causative mechanism of cellular senescence and ageing. Curr. Opin. Genet. Dev. 26: 89-95. http://dx.doi.org/10.1016/j.gde.2014.06.009

Safarzadeh-Amiri A, Fowlie P, Kazi AI, Siraj S, et al. (2011). Validation of analysis of arsenic in water samples using Wagtech Digital Arsenator. Sci. Total Environ. 409: 2662-2667. http://dx.doi.org/10.1016/j.scitotenv.2011.03.016

Shibata T, Meng C, Umoren J and West H (2016). Risk assessment of arsenic in rice cereal and other dietary sources for infants and toddlers in the U.S. Int. J. Environ. Res. Public. Health. 13: 361. 1-10.

Genetics and Molecular Research 16 (2): gmr16029241 
Singh NP, McCoy MT, Tice RR and Schneider EL (1988). A simple technique for quantitation of low levels of DNA damage in individual cells. Exp. Cell Res. 175: 184-191. http://dx.doi.org/10.1016/0014-4827(88)90265-0

Tian D, Ma H, Feng Z, Xia Y, et al. (2001). Analyses of micronuclei in exfoliated epithelial cells from individuals chronically exposed to arsenic via drinking water in inner Mongolia, China. J. Toxicol. Environ. Health A 64: 473484. http://dx.doi.org/10.1080/152873901753215939

Vuyyuri SB, Ishaq M, Kuppala D, Grover P, et al. (2006). Evaluation of micronucleus frequencies and DNA damage in glass workers exposed to arsenic. Environ. Mol. Mutagen. 47: 562-570. http://dx.doi.org/10.1002/em.20229

WHO (2004) Guideline for drinking water quality, background document for development arsenic in drinking-water Geneva: 1: 41.

Xia Y, Wade TJ, Wu K, Li Y, et al. (2009). Well water arsenic exposure, arsenic induced skin-lesions and self-reported morbidity in Inner Mongolia. Int. J. Environ. Res. Public Health 6: 1010-1025. http://dx.doi.org/10.3390/ ijerph6031010

Genetics and Molecular Research 16 (2): gmr16029241 